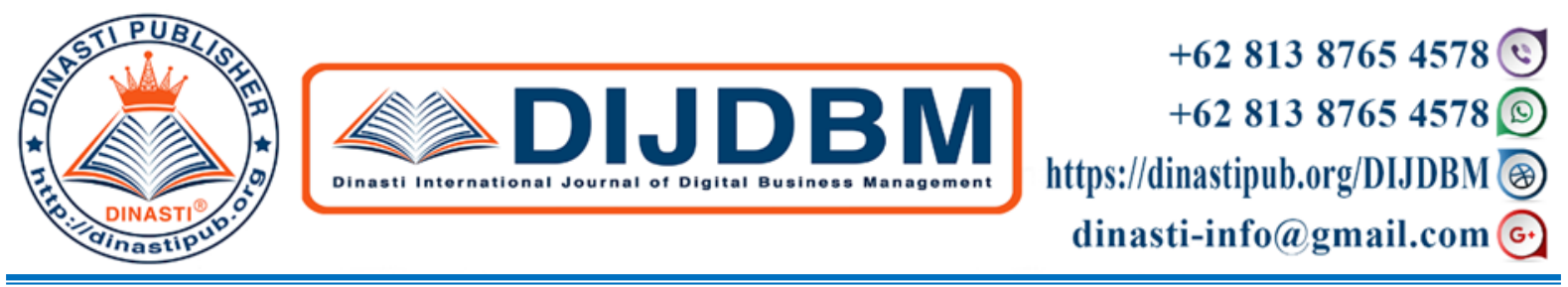

\title{
THE EFFECT OF INTERNET QUALITY CONNECTION AND AFTER SALES SERVICE TOWARDS CONSUMERS' SATISFACTION AND ITS IMPLICATION ON CONSUMERS' LOYALITY OF SATELLITE INTERNET PRODUCT MANGOESKY PT. TELKOMSAT
}

Nur Sugianto ${ }^{1}$, Arifin Sitio ${ }^{2}$

1) Mercu Buana University, Jakarta, Indonesia

2) Mercu Buana University, Jakarta, Indonesia

ARTICLE INFORMATION

Received: $24^{\text {th }}$ June 2020

Revised: $20^{\text {th }}$ July 2020

Issued: $23^{\text {th }}$ August 2020

Corresponding author:

First author

Email:

antho.ns01@gmail.com arifin.sitio@mercubuana.ac.id

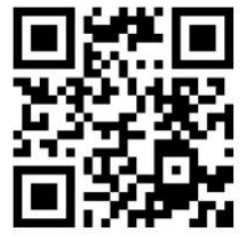

DOI:10.31933/DIJDBM
Abstract: This study is aimed to analyze the effect of internet quality connection and after sales service towards consumers' satisfaction and its implication on consumers' loyalty of internet product MangoeSky Satellite PT. Telkomsat. The type of research used in this study is casual research. The population of this study is all permanent consumers of internet service MangoeSky satellite PT. Telkomsat, which is 4.108 subscribers. The determination of sample number was conducted by using slovin formula with the result that obtained 100 respondents. The analysis method used is the regression analysis test through SPSS version 25 . The results of this study show that (1) Service quality has a positive and significant effect on consumers' satisfaction, (2) After sales service has a positive and significant effect on consumers' satisfaction, (3) Service quality has a positive and significant effect on consumers' loyalty, (4) After sales service has a positive and significant effect on consumers' loyalty, (5) Consumers' satisfaction has a positive and significant effect on consumers' loyalty, and (6) There is a positive indirect effect between service quality and after sales service for loyalty through consumers' satisfaction, it means that consumers' satisfaction can increase consumers' loyalty.

Keywords: Consumers' loyalty, Consumers' satisfaction, After sales service, Service quality

\section{INTRODUCTION}

Today, internet is one of the most inseparable primary needs from one's life, regardless of where he/she lives. Probably, for some people internet can be very needed thing but for some, it doesn't. For those who make data packages as a side requirement will not be confused when they get a notification that the data quota, he has will be expired. This is inseparable from the environment around us. If you are in an environment that makes the 
internet one of the most important things, then inevitably you have to use an internet data plan. It cannot be denied that the internet becomes a tool to access the needed information quickly. Some people today such as community, government, companies, education activists and health workers use the internet to help accessing information and to facilitate their works. Health is one of the important issues for which so many people are looking for information on the internet.

Based on the fact above, there are many things are being done by the Indonesian government to bring forward public health in this digital era, as we all know, health service related to the community was far from adequate. As a form of manifestation of the improvements made is revamping the health center services. Recognizing the role of puskesmas as the spearhead of health services to the community, facilities and assistive infrastructure are needed to facilitate, to speed up and to improve the quality of services provided by puskesmas.

Encouraged to be able realizing the best service immediately, the demands of all facilities must also follow one another. The presence of several health applications such as ePuskesmas and BPJS p-Care are very helpful and facilitates puskesmas in handling patients. The services provided to patients become faster, and the patients' medical records become easier to store so that puskesmas does not have to bother looking for patients' files, especially if there are handwriting that is difficult to read.

However, all of these applications will not work without internet network at the puskesmas. As we know, due to the geographical condition of Indonesia which consists of islands, the distribution of internet and communication networks cannot be enjoyed even in remote areas. There are still many health centers in remote areas serve patients manually because there is no internet network.

More and more needs for internet services bring about many parties find that internet services as a profitable business opportunity. One of them is PT. Telkomsat. This company provides internet service based on satellite to fulfill the need of retail consumers, UKM/SME as well as government which is not covered by terrestrial, optical or cellular telephone networks.

The are many parties become internet service providers, thus the competition to dominate the market is getting tougher. The companies use many ways to maintain their consumers, one of them is to ensure the quality of product and service.

The service and the facility which are having a certain quality, are two main factors which must be considered to win the competition because it generates its own attractiveness for consumers and supports achieved consumers' satisfactions towards product/service and furthermore it will influence consumers' loyalties for the services prepared.

Talking about the service means talking about satisfaction or dissatisfaction that arise from the service. The products and services provided may not satisfy all users (consumers). This is due to different consumer tastes, so the level of satisfaction felt can also vary.

Before conducting this study, the writer first conducted pre-survey on the object of research with 20 respondents who were Puskesmas Operators. The pre-survey results, as seen in the picture below, show that there are 3 main factors allegedly to influence consumers' satisfaction with MangoeSky services, namely Internet Service Quality, Clarity of Internet Service Features, and Speed of After Sales Service in dealing with internet connection disruptions. 


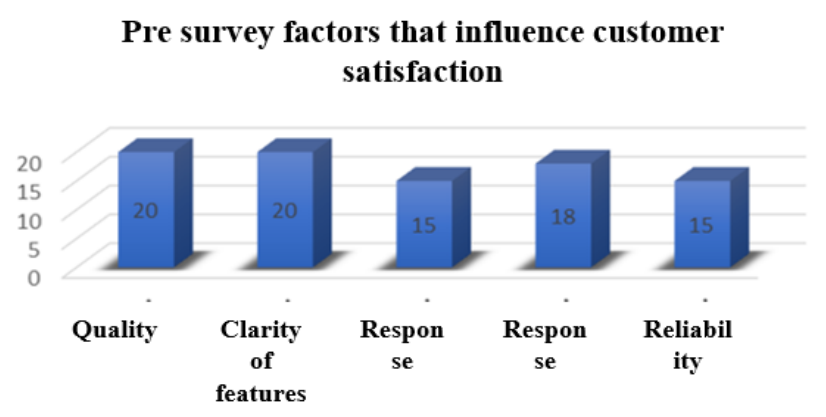

Figure 1. The Result of Pre-Survey (2019)

\section{LITERATURE REVIEW}

Service quality. Tjiptono (2012) defines service quality simply, which is a measure of how well the level of service provided is able to match customer expectations. This means that service quality is determined by the company's ability to meet the needs in accordance with what is expected by the customer. The concept of service quality is a way to measure the service activities of an organization through the performance of its officers to consumers as service users. In this case what needs to be understood is that service in the form of an activity carried out to provide benefits to consumers as offered by an organization or individual. In Tjiptono \& Chandra (2011: 232) the dimensions of service quality consist of Tangibles (Physical Evidence), Empathy, Reliability, Responsiveness, Assurance. A service can be said to have good quality if it includes these dimensions. With this dimension, it is expected to have more value compared to competitors, building the quality of a service is a strategic step that must be taken by the company. This is because the quality of a service is a superior value in the eyes of customers. Therefore, service quality is very important for a company, because the basis for true loyalty lies in consumers' satisfaction where service quality is the main input.

Internet. Allan (2005), explains that the internet is a collection of computer networks that are physically connected to each other and also has the ability to read and decipher various communication protocols that are often familiar with the term Internet Protocol (IP) and Transmission Control Protocol (TCP). The protocol itself, was further defined by Alan as a simple specification of how two or more computers could exchange information. Another opinion states that the Internet can be interpreted as a collection of several computers, which can even reach millions of computers throughout the world that can be interconnected and connected to each other. So that computers can copy connected to one another, then media is needed to connect between computers. The media used can use optical fiber / cable, satellite or through telephone connections (Harjono, 2009).

After Sales Service. After-sales service has emerged as a major source of competitive maneuvering, so companies strive to create competitive advantage by creating a portfolio of after sales service with offers that differ from competitors (Goffin, 1994., Slater, 1996; in Ruben, 2012). According to Ganon in Tanoto (2012) after-sales service is a service provided to customers after customers buy products. Components of after sales service consist of:
a. The warranty
b. Spare parts availability
c. Technician Services
d. Supporting facilities and Tools

Consumers' satisfaction. Consumers' satisfaction is the response of the behavior exhibited by the customer by comparing the perceived performance or results with expectations. If the results are felt below expectations, then the customer will be disappointed, less satisfied or even dissatisfied, but vice versa if according to expectations, 
the customer will be satisfied and if the performance exceeds expectations, the customer will be very satisfied (Kotler et. Al, 2007). Dimensions regarding consumers' satisfaction have been published by Kotler cited by Rosmalina (2018), as follows:

1) Conformity of customer expectations

Customers will compare the suitability of expectations before and after buying or using the product or service offered.

2) Perception of work results

It is a customer assessment in the form of perceptions of services received by customers.

3) Customer ratings

It is a comprehensive assessment of the superiority of a company's products or services compared to competitors' products.

Consumers' loyalty. Sitio (2019) explains that consumer loyalty is something rooted in consumer insight, which has a satisfying relationship with a product or service provider. Kotler and Keller (2012) define loyalty as a firm commitment to repurchase or subscribe to a choice of product or service, even though situational influences and marketing efforts have the potential to cause consumers to switch to other products. According to Griffin in Sangadji and Sopiah (2013) loyal customers have the following characteristics:

1) Making regular purchases (make regular repeat purchases/repetition)

2) Buying outside the product or service line (purchases across products and service lines/Referrals).

3) Referring company products to other people (Refers other).

4) Demonstrating immunity from the appeal of similar products from competitors (Demonstrates an immunity to the full of the competition/Retention).

Loyalty is very crucial aspect to the company. Thus, the company should continue to maintain and increase the loyalty of its customers.

\section{Types of research.}

The writer uses Causal Research in this. It is used to prove the relationship between cause and effect of several variables. Causal research usually uses the experimental method by controlling the independent variable that will affect the dependent variable (Sugiyono, 2014). This research was conducted with a descriptive method and with a quantitative approach. Quantitative analysis itself was chosen because in this study the writer tries to determine the relationship between variables used values expressed in the form of numbers, which will be obtained mathematically with a statistical formula.

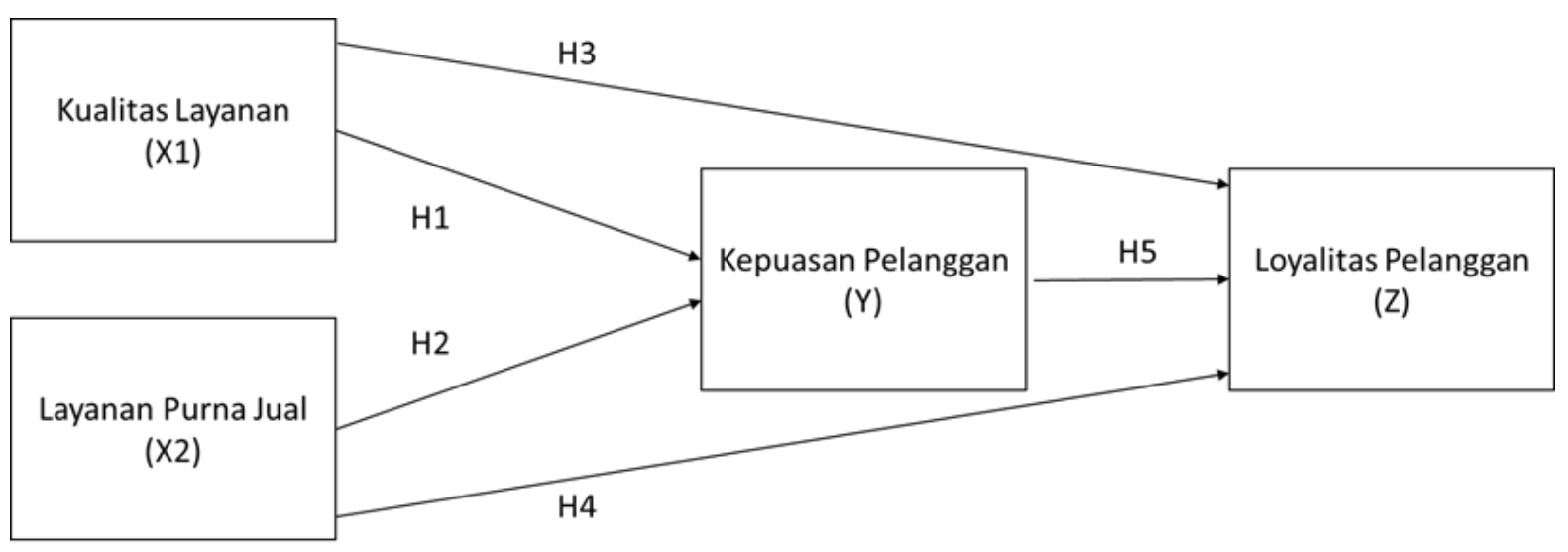

Figure 2. Framework 


\section{Population and Sample}

According to Sugiyono (2012: 80), population is a generalization area consisting of objects or subjects that have certain qualities and characteristics, determined by researchers to be studied and then drawn conclusions. So, the population is not only people, but also objects and other natural objects. Population is also not just the amount that exists on the object or subject studied, but includes all the characteristics or properties possessed by the subject or object. Based on data as of May 2019 the total population of consumers remains MangoeSky satellite internet service PT. Telkomsat is 4,108 subscribers. This data will be used as a basis for the population of researchers. In this study, samples taken by sampling area (cluster) sampling or can also be called cluster sampling. The area sampling technique is used to determine the sample if the object to be studied or the data source is very broad, for example residents of a country, province or district. To determine which population will be used as a data source, the sampling is based on a predetermined population area (Sugiyono, 2008: 85). From the description of cluster sampling, it can be concluded that the selection of sample members is done in groups and not individual sample members. Determination of the number of samples using the slovin formula so that 100 respondents were obtained who are puskesmas operators using MangoeSky satellite internet service PT. Telkomsat.

\section{Data analysis method}

Regression analysis test is used to draw a line that shows the direction of the relationship between variables, and is used to make predictions. This analysis is used to analyze the relationship between two or more variables, especially to explore the pattern of relationships whose models are not yet fully known. Regression consisting of one independent variable (predictor) and one dependent variable (Response / Criterion) is called a simple linear regression (bivariate regression), whereas a regression with more than one independent variable is called multiple regression (Multiple Regression / Multivariate regression), which can consist of two predictors (multiple regression) or more. This study uses path regression analysis through SPSS 25 software.

\section{THE RESULT OF THE STUDY AND DISCUSSION}

This study is aimed to analyze the effect of internet quality connection and after sales service towards consumers' satisfaction and its implication on consumers' loyalty of internet product MangoeSky Satellite PT. Telkomsat. The data collection process was carried out through a research questionnaire instrument with a total 100 respondents who were Puskesmas operators, they are users of MangoeSky satellite internet service PT. Telkomsat.

Table 1. Validity Test of Service Quality Variable

\begin{tabular}{|c|l|r|r|c|}
\hline \multirow{2}{*}{ No } & \multicolumn{1}{|c|}{ Questions } & \multicolumn{3}{c|}{ Result } \\
\cline { 2 - 5 } & \multicolumn{1}{|c|}{ Service Quality $\left(\mathbf{X}_{1}\right)$} & r Table & Conclusion \\
\hline \multicolumn{5}{|c|}{ Tangibility } \\
\hline 1 & $\begin{array}{l}\text { The MangoeSky service kit which is sent to } \\
\text { the location is neatly wrapped }\end{array}$ & 0.867 & 0.361 & Valid \\
\hline 2 & $\begin{array}{l}\text { The condition of the device (Antenna, Modem, } \\
\text { STB and Wi-Fi Access Point) is in good } \\
\text { condition and functioning normally }\end{array}$ & 0.652 & 0.361 & Valid \\
\hline
\end{tabular}




\begin{tabular}{|c|c|c|c|c|}
\hline 3 & $\begin{array}{l}\text { The process of installing the device on location } \\
\text { looks good and neat, and there is no physical } \\
\text { damage to the location that is installed with } \\
\text { MangoeSky devices }\end{array}$ & 0.807 & 0.361 & Valid \\
\hline \multicolumn{5}{|c|}{ Responsiveness } \\
\hline 4 & $\begin{array}{l}\text { Friendly treatment, polite service and } \\
\text { responsive officer towards consumers }\end{array}$ & 0.819 & 0.361 & Valid \\
\hline 5 & $\begin{array}{l}\text { Providing education to customers when trying } \\
\text { a MangoeSky internet connection as a proof } \\
\text { that the service is functioning properly }\end{array}$ & 0.943 & 0.361 & Valid \\
\hline 6 & $\begin{array}{l}\text { Providing the contact of Care Center } \\
\text { information that can be contacted if there is a } \\
\text { disruption in the MangoeSky service }\end{array}$ & 0.943 & 0.361 & Valid \\
\hline \multicolumn{5}{|c|}{ Reliability } \\
\hline 7 & $\begin{array}{l}\text { The process of installing MangoeSky services } \\
\text { is in accordance with the promised timeliness } \\
\text { when customers place an order }\end{array}$ & 0.863 & 0.361 & Valid \\
\hline 8 & $\begin{array}{l}\text { MangoeSky services that are installed is } \\
\text { accordance with the internet package that } \\
\text { customers want }\end{array}$ & 0.819 & 0.361 & Valid \\
\hline 9 & $\begin{array}{l}\text { The services provided related to package } \\
\text { transfer and improvement of service quality } \\
\text { are always responded properly }\end{array}$ & 0.807 & 0.361 & Valid \\
\hline \multicolumn{5}{|c|}{ Assurance } \\
\hline 10 & $\begin{array}{l}\text { MangoeSky provides a warranty against } \\
\text { damage to the device during the subscription } \\
\text { period at no additional charge }\end{array}$ & 0.905 & 0.361 & Valid \\
\hline 11 & $\begin{array}{l}\text { MangoeSky provides stable internet services in } \\
\text { any condition, including even in bad weather } \\
\text { conditions }\end{array}$ & 0.744 & 0.361 & Valid \\
\hline 12 & $\begin{array}{l}\text { MangoeSky provides guarantees that the } \\
\text { services provided are in accordance with the } \\
\text { internet package that is needed by the } \\
\text { customers }\end{array}$ & 0.802 & 0.361 & Valid \\
\hline \multicolumn{5}{|c|}{ Empathy } \\
\hline 13 & $\begin{array}{l}\begin{array}{l}\text { MangoeSky provides convenience in } \\
\text { submitting customers' complaints }\end{array} \\
\end{array}$ & 0.819 & 0.361 & Valid \\
\hline 14 & $\begin{array}{l}\text { MangoeSky always responds to every } \\
\text { complaint and report from customers }\end{array}$ & 0.730 & 0.361 & Valid \\
\hline 15 & $\begin{array}{l}\text { Confirmation and education are always } \\
\text { provided to customers for any service } \\
\text { interruptions that have been handled }\end{array}$ & 0.730 & 0.361 & Valid \\
\hline
\end{tabular}

Source: Output SPSS 25, Data processed

Based on table 1 , validity test of the service quality variable items, $t$ is known that all dimensions of the service quality variable are valid. That is because the value of $r$ Calculate> 
$r$ Table. From the number of respondents $n=30$ and the significance level of $5 \%$ with the formula $\mathrm{df}=\mathrm{n}-2$, the value of $\mathrm{r}$ Table $=0.361$ is obtained. These results indicate that all dimensions can be used to measure variables of service quality. Thus, the questionnaire can be used as a research instrument.

Table 2. Validity Test of After Sales Service Variable

\begin{tabular}{|c|c|c|c|c|}
\hline \multirow{2}{*}{ No } & \multirow{2}{*}{ Question } & \multicolumn{3}{|c|}{ Result } \\
\hline & & r Count & r Table & Conclusion \\
\hline \multicolumn{5}{|c|}{ After Sales (X2) } \\
\hline \multicolumn{5}{|c|}{ The warranty } \\
\hline 1 & $\begin{array}{l}\text { If there is damage and disruption to the service } \\
\text { and the MangoeSky device, it will be } \\
\text { immediately handled and checked according } \\
\text { to the SOP service }\end{array}$ & 0.954 & 0.361 & Valid \\
\hline 2 & $\begin{array}{l}\text { The MangoeSky After Sales Services team is } \\
\text { always ready and acting fast in receiving } \\
\text { complaints and immediately following up on } \\
\text { all complaints from customers }\end{array}$ & 0.933 & 0.361 & Valid \\
\hline 3 & $\begin{array}{l}\text { The process of handling MangoeSky's service } \\
\text { interruption is in accordance with the } \\
\text { promised SLA }\end{array}$ & 0.954 & 0.361 & Valid \\
\hline \multicolumn{5}{|c|}{ Parts Availability } \\
\hline 4 & $\begin{array}{l}\text { MangoeSky always guarantees the } \\
\text { replacement of damaged devices to the } \\
\text { customer without additional costs }\end{array}$ & 0.890 & 0.361 & Valid \\
\hline 5 & $\begin{array}{l}\text { MangoeSky always provides stock of } \\
\text { equipment at each base / warehouse as a } \\
\text { backup device in the event of damage to the } \\
\text { device installed at the customer's location }\end{array}$ & 0.698 & 0.361 & Valid \\
\hline 6 & $\begin{array}{l}\text { The process of replacing and reinstalling the } \\
\text { device at the customer's location is in } \\
\text { accordance with the promised SOP and SLA } \\
\text { services }\end{array}$ & 0.752 & 0.361 & Valid \\
\hline \multicolumn{5}{|c|}{ Technician Services } \\
\hline 7 & $\begin{array}{l}\text { MangoeSky technicians are available at each } \\
\text { base / warehouse and have the same ability to } \\
\text { carry out installation reliably and repair work } \\
\text { in the field }\end{array}$ & 0.940 & 0.361 & Valid \\
\hline 8 & $\begin{array}{l}\text { MangoeSky's technicians are always friendly } \\
\text { and polite in appearance when doing work in } \\
\text { the field }\end{array}$ & 0.788 & 0.361 & Valid \\
\hline 9 & $\begin{array}{l}\text { MangoeSky technicians are always ready to } \\
\text { answer complaints and explain in detail related } \\
\text { to customer needs }\end{array}$ & 0.917 & 0.361 & Valid \\
\hline & porting Facilities and Tools & & & \\
\hline
\end{tabular}




\begin{tabular}{|c|l|r|r|c|}
10 & $\begin{array}{l}\text { MangoeSky has a monitoring dashboard } \\
\text { system that can monitor the quality of services } \\
\text { installed at each customer's location }\end{array}$ & 0.940 & 0.361 & Valid \\
\hline 11 & $\begin{array}{l}\text { MangoeSky has a Care Center that easily to } \\
\text { contact at any time, and operates 24 hours x } \\
\text { days that monitor the monitored services } \\
\text { online / offline on the customer side }\end{array}$ & 0.792 & 0.361 & Valid \\
\hline 12 & $\begin{array}{l}\text { Interference monitoring system from After } \\
\text { sales service is running well }\end{array}$ & 0.788 & 0.361 & Valid \\
\hline
\end{tabular}

Source: Output SPSS 25, Data processed

Based on table 2, the validity test on variable item after-sales service, it is known that all dimensions of the after-sales service variables are valid. That is because the value of $r$ Calculate $>r$ Table. From the number of respondents $n=30$ and the significance level of 5\% with the formula $\mathrm{df}=\mathrm{n}-2$, the value of $\mathrm{r}$ Table $=0.361$ is obtained. These results indicate that all dimensions can be used to measure after-sales service variables. So, the questionnaire can be used as a research instrument.

Table 3. Validity Test of Consumers' Satisfaction Variable

\begin{tabular}{|c|c|c|c|c|}
\hline \multirow{2}{*}{ No } & \multirow{2}{*}{ Question } & \multicolumn{3}{|c|}{ Result } \\
\hline & & r Count & r Table & Conclusion \\
\hline \multicolumn{5}{|c|}{ Consumers' Satisfaction (Y) } \\
\hline \multicolumn{5}{|c|}{ Conformity of Customer Expectations } \\
\hline 1 & $\begin{array}{l}\text { MangoeSky Internet services provided are in } \\
\text { accordance with customer needs }\end{array}$ & 0.583 & 0.361 & Valid \\
\hline 2 & $\begin{array}{l}\text { Quota package or connection speed provided } \\
\text { by MangoeSky internet service as } \\
\text { corresponding promised }\end{array}$ & 0.736 & 0.361 & Valid \\
\hline 3 & $\begin{array}{l}\text { MangoeSky provides convenience in filling } \\
\text { out quotas of service package or reporting } \\
\text { interruptions }\end{array}$ & 0.736 & 0.361 & Valid \\
\hline \multicolumn{5}{|c|}{ Work Results Perception } \\
\hline 4 & $\begin{array}{l}\text { The connection speed and packet quota for } \\
\text { MangoeSky services provided already meets } \\
\text { the needs of the customer }\end{array}$ & 0.748 & 0.361 & Valid \\
\hline 5 & $\begin{array}{l}\text { MangoeSky Internet service has a fairly stable } \\
\text { connection even in bad weather conditions }\end{array}$ & 0.686 & 0.361 & Valid \\
\hline 6 & $\begin{array}{l}\text { MangoeSky Internet services rarely run into } \\
\text { interruptions, so SLA services are maintained }\end{array}$ & 0.686 & 0.361 & Valid \\
\hline \multicolumn{5}{|c|}{ Customer Ratings } \\
\hline 7 & $\begin{array}{l}\text { You are satisfied with connection and quota } \\
\text { package of MangoeSky Internet }\end{array}$ & 0.583 & 0.361 & Valid \\
\hline 8 & $\begin{array}{l}\text { You are satisfied with the after sales service } \\
\text { provided by the MangoeSky Internet After } \\
\text { Sales Services team }\end{array}$ & 0.583 & 0.361 & Valid \\
\hline 9 & $\begin{array}{l}\text { MangoeSky Internet services are superior to } \\
\text { other similar providers }\end{array}$ & 0.583 & 0.361 & Valid \\
\hline
\end{tabular}


Source: Output SPSS 25, Data processed

Based on table 3, the validity test on the item variable consumers' satisfaction, it is known that all dimensions on the consumers' satisfaction variable are valid. That is because the value of $r$ Calculate> $r$ Table. From the number of respondents $n=30$ and the significance level of $5 \%$ with the formula $\mathrm{df}=\mathrm{n}-2$, the value of $\mathrm{r}$ Table $=0.361$ is obtained. These results indicate that all dimensions can be used to measure consumers' satisfaction variable. So, the questionnaire can be used as a research instrument.

Table 4. Validity Test of Consumers' Loyalty Variable

\begin{tabular}{|c|c|c|c|c|}
\hline \multirow{2}{*}{ No } & \multirow{2}{*}{ Question } & \multicolumn{3}{|c|}{ Result } \\
\hline & & r Count & r Table & Conclusion \\
\hline \multicolumn{5}{|c|}{ Consumers' Loyalty (Z) } \\
\hline \multicolumn{5}{|c|}{ Repurchase } \\
\hline 1 & \begin{tabular}{|l} 
You will continue to subscribe to \\
MangoeSky's internet service
\end{tabular} & 0.771 & 0.361 & Valid \\
\hline 2 & $\begin{array}{l}\text { You will add a MangoeSky internet service } \\
\text { reservation to be installed in other locations }\end{array}$ & 0.966 & 0.361 & Valid \\
\hline 3 & $\begin{array}{l}\text { You will often fill in the quota for MangoeSky } \\
\text { internet service packages }\end{array}$ & 0.771 & 0.361 & Valid \\
\hline \multicolumn{5}{|c|}{ Buy between service lines } \\
\hline 4 & $\begin{array}{l}\text { You will buy a variety of other quota packages } \\
\text { offered by MangoeSky internet services }\end{array}$ & 0.862 & 0.361 & Valid \\
\hline 5 & $\begin{array}{l}\text { You will upgrade the MangoeSky internet } \\
\text { service connection bandwidth from the } \\
\text { previous service }\end{array}$ & 0.427 & 0.361 & Valid \\
\hline 6 & $\begin{array}{l}\text { You will buy MangoeSky internet service } \\
\text { tools as personal assets as needed }\end{array}$ & 0.862 & 0.361 & Valid \\
\hline \multicolumn{5}{|c|}{ Referrals } \\
\hline 7 & $\begin{array}{l}\text { You will recommend the MangoeSky service } \\
\text { to relatives or other parties }\end{array}$ & 0.950 & 0.361 & Valid \\
\hline 8 & $\begin{array}{l}\text { You are willing to tell positive things about } \\
\text { MangoeSky's internet service to relatives or } \\
\text { other parties }\end{array}$ & 0.950 & 0.361 & Valid \\
\hline 9 & $\begin{array}{l}\text { You are willing to give testimonials and } \\
\text { become a reference for others if someone asks } \\
\text { about the quality of MangoeSky's internet } \\
\text { services }\end{array}$ & 0.950 & 0.361 & Valid \\
\hline \multicolumn{5}{|c|}{ Retention } \\
\hline 10 & $\begin{array}{l}\text { MangoeSky internet service is the main choice } \\
\text { when you need an internet connection for rural } \\
\text { areas }\end{array}$ & 0.584 & 0.361 & Valid \\
\hline 11 & $\begin{array}{l}\text { You will not be affected by similar products } \\
\text { despite being offered a cheaper price }\end{array}$ & 0.903 & 0.361 & Valid \\
\hline 12 & $\begin{array}{l}\text { You will still subscribe to MangoeSky even } \\
\text { though there is a price change that is more } \\
\text { expensive }\end{array}$ & 0.903 & 0.361 & Valid \\
\hline
\end{tabular}


Source: Output SPSS 25, Data processed

Based on table 4, the validity test on the consumers' loyalty variable item, it is known that all dimensions on the consumers' loyalty variable are valid. That is because the value of $r$ Calculate> $r$ Table. From the number of respondents $n=30$ and the significance level of 5\% with the formula $\mathrm{df}=\mathrm{n}-2$, the value of $\mathrm{r}$ Table $=0.361$ is obtained. These results indicate that all dimensions can be used to measure consumers' loyalty variable. So, the questionnaire can be used as a research instrument.

Table 5. The Result of Research Variable Reliability

\begin{tabular}{|l|c|c|c|}
\hline \multicolumn{1}{|c|}{ Variable } & Cronbanch's Alpha & $\begin{array}{c}\text { Cronbanch's Alpha } \\
\text { Standard }\end{array}$ & Conclusion \\
\hline Service Quality & 0.926 & 0.60 & Reliable \\
\hline After Sales Service & 0.923 & 0.60 & Reliable \\
\hline $\begin{array}{l}\text { Consumers' } \\
\text { Satisfaction }\end{array}$ & 0.642 & 0.60 & Reliable \\
\hline Consumers' Loyalty & 0.952 & 0.60 & Reliable \\
\hline
\end{tabular}

Source: Output SPSS 25, Data processed

From the table 5 above, it can be seen that the Cronbach's Alpha value for the variable service quality $\left(\mathrm{X}_{1}\right)$, after sales service $\left(\mathrm{X}_{2}\right)$, consumers' satisfaction $(\mathrm{Y})$, and consumers' loyalty $(Z)$ is above 0.60 , so it can be concluded that the questionnaire items can be said reliable or trusted as a data collection tool in this study.

Table 6. The Result of Normality Test

One-Sample Kolmogorov-Smirnov Test

\begin{tabular}{|l|l|r|}
\hline \multicolumn{2}{|l|}{} & \multicolumn{2}{|c|}{ Unstandardized Residual } \\
\hline N & \multicolumn{2}{|c|}{100} \\
\hline \multirow{2}{*}{ Normal Parameters } & Mean & 0.0000000 \\
\cline { 2 - 4 } & Std. Deviation & 2.57845491 \\
\hline $\begin{array}{l}\text { Most Extreme } \\
\text { Differences }\end{array}$ & Absolute & 0.990 \\
\cline { 2 - 4 } & Positive & 0.890 \\
\cline { 2 - 4 } & Negative & -0.990 \\
\hline Test Statistic & & 0.990 \\
\hline Asymp. Sig. (2-tailed) & & $.430^{c}$ \\
\hline
\end{tabular}

a. Test distribution is Normal.

b. Calculated from data.

c. Lilliefors Significance Correction.

Source: Output SPSS 25, Data processed

Based on table 6, it can be concluded that the data are normally distributed. That is because the Asymp value. Sig. (2-tailed) of 0.430 or greater than 0.05 (Ghozali, 2013: 34). 
Table 7. The Result of Data Multicollinearity

\begin{tabular}{|l|c|c|c|}
\hline \multicolumn{1}{|c|}{ Variabel } & Tolerance & VIF & Kesimpulan \\
\hline Service Quality & 0.836 & 5.962 & There is no multicollinearity \\
\hline After Sales Service & 0.827 & 6.086 & There is no multicollinearity \\
\hline Consumers' Satisfaction & 0.914 & 2.094 & There is no multicollinearity \\
\hline
\end{tabular}

Source: Output SPSS 25, Data processed

Based on table 7 above, for the variable Service Quality, After Sales Service and Consumers' satisfaction seen to have a VIF value smaller than 10 . While the Tolerance value is greater than 10 percent or 0.1 . This shows that the independent/independent variables in this study do not correlate with each other or that there is no correlation between the independent variables, so the model does not contain multicollinearity.

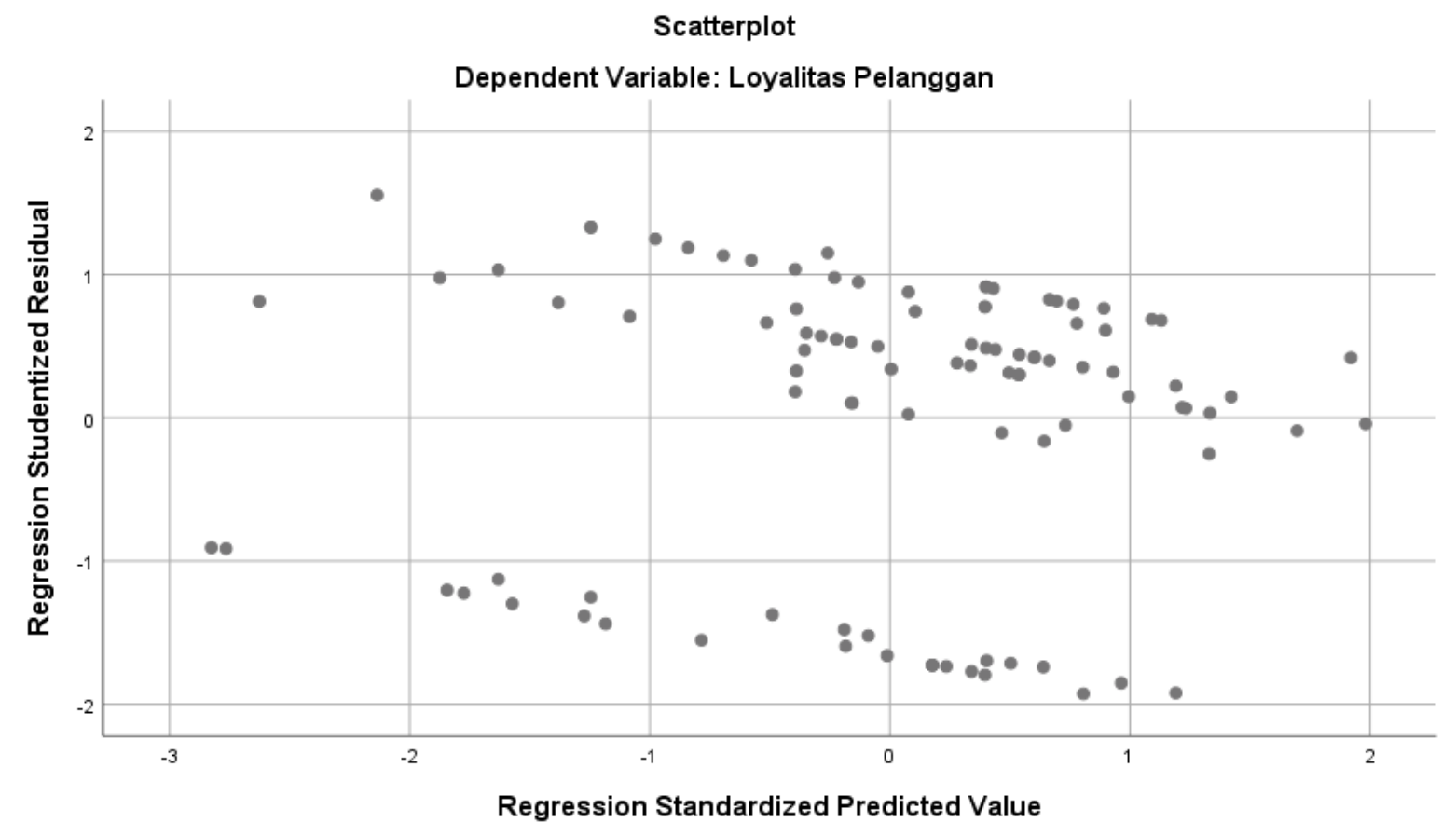

Figure 3. The Result of Heteroscedasticity Test

From Figure 3 above, scatterplot shows that the points spread randomly and spread both above and below the number 0 (zero) on the $\mathrm{Y}$ axis. It can be concluded that there was no heteroscedasticity in the regression model. So that the regression model is feasible to be used to predict Consumers' loyalty based on input of independent variables, namely Service Quality, After Sales Service and Consumers' Satisfaction. From the tests that have been carried out it can be concluded that the data is normally distributed, there is no autocorrelation, multicollinearity, and heteroscedasticity so that it meets the requirements for path analysis. Before passing the path analysis test, here are the results of testing the hypothesis in this study. 
Table 8. The Effect of Service Quality $\left(\mathrm{X}_{1}\right)$ towards Consumers' Satisfaction (Y)

\begin{tabular}{|l|l|r|r|r|r|r|}
\hline \multicolumn{2}{|l|}{ Model } & \multicolumn{2}{|c|}{$\begin{array}{c}\text { Unstandardized } \\
\text { Coefficients }\end{array}$} & $\begin{array}{c}\text { Standardized } \\
\text { Coefficients }\end{array}$ & \multirow{2}{*}{$\mathrm{t}$} & \multirow{2}{*}{ Sig. } \\
\cline { 3 - 6 } \multicolumn{2}{|c|}{} & \multicolumn{1}{|c|}{ B } & $\begin{array}{c}\text { Std. } \\
\text { Error }\end{array}$ & Beta & & \\
\hline \multirow{2}{*}{} & (Constant) & 30.859 & 2.272 & & 13.584 & 0.000 \\
\cline { 2 - 6 } & Service Quality & 0.101 & 0.035 & 0.276 & 2.845 & 0.005 \\
\hline
\end{tabular}

Source: Output SPSS 25, Data processed

Based on table 8 , it is known that the sig value of $0.005<0.05$. This shows that Service Quality $\left(\mathrm{X}_{1}\right)$ significantly effect on Consumers' Satisfaction $(\mathrm{Y})$. In other words, Hypothesis 1 (H1) is accepted.

Table 9. The Effect of After Sales Service $\left(\mathbf{X}_{2}\right)$ towards Consumers' Satisfaction (Y)

\begin{tabular}{|c|c|c|c|c|c|}
\hline \multirow[t]{2}{*}{ Model } & \multicolumn{2}{|c|}{$\begin{array}{l}\text { Unstandardized } \\
\text { Coefficients }\end{array}$} & \multirow{2}{*}{$\begin{array}{c}\begin{array}{c}\text { Standardize } \\
\text { d }\end{array} \\
\text { Coefficients } \\
\text { Beta }\end{array}$} & \multirow[t]{2}{*}{$\mathrm{t}$} & \multirow[t]{2}{*}{ Sig. } \\
\hline & B & $\begin{array}{c}\text { Std. } \\
\text { Error }\end{array}$ & & & \\
\hline (Constant) & 31.965 & 1.771 & & 18.047 & 0.000 \\
\hline After Sales Service & 0.107 & 0.035 & 0.293 & 3.033 & 0.003 \\
\hline
\end{tabular}

Source: Output SPSS 25, Data processed

Based on table 9, it is known that the sig value is $0.003<0.05$. This shows that After Sales Service $\left(\mathrm{X}_{2}\right)$ has a significant effect on Consumers' Satisfaction (Y). In other words, Hypothesis $2(\mathrm{H} 2)$ is accepted.

Table 10. The Effect of Quality Service $\left(X_{1}\right)$ towards Consumers' Loyalty $(Z)$

\begin{tabular}{|c|c|c|c|c|c|}
\hline \multirow[t]{2}{*}{ Model } & \multicolumn{2}{|c|}{$\begin{array}{l}\text { Unstandardized } \\
\text { Coefficients }\end{array}$} & $\begin{array}{c}\text { Standardize } \\
\text { d } \\
\text { Coefficients }\end{array}$ & \multirow[t]{2}{*}{$\mathrm{t}$} & \multirow[t]{2}{*}{ Sig. } \\
\hline & B & $\begin{array}{l}\text { Std. } \\
\text { Error }\end{array}$ & Beta & & \\
\hline (Constant) & 33.983 & 6.308 & & 5.387 & 0.000 \\
\hline Service Quality & 0.214 & 0.098 & 0.215 & 2.181 & 0.002 \\
\hline
\end{tabular}

Source: Output SPSS 25, Data processed

Based on table 10, it is known that the sig value of $0.002<0.05$. This shows that Service Quality $\left(\mathrm{X}_{1}\right)$ has a significant effect towards Consumers' Loyalty $(\mathrm{Z})$. In other words, Hypothesis 3 (H3) is accepted. 
Table 11. The Effect of After Sales Service $\left(X_{2}\right)$ towards Consumers' Loyalty $(Z)$

\begin{tabular}{|c|c|c|c|c|c|}
\hline \multirow[t]{2}{*}{ Model } & \multicolumn{2}{|c|}{$\begin{array}{l}\text { Unstandardized } \\
\text { Coefficients }\end{array}$} & \multirow{2}{*}{$\begin{array}{c}\begin{array}{c}\text { Standardize } \\
\text { d } \\
\text { Coefficients }\end{array} \\
\text { Beta }\end{array}$} & \multirow[t]{2}{*}{$\mathrm{t}$} & \multirow[t]{2}{*}{ Sig. } \\
\hline & B & $\begin{array}{c}\text { Std. } \\
\text { Error }\end{array}$ & & & \\
\hline (Constant) & 36.146 & 4.925 & & 7.340 & 0.000 \\
\hline After Sales Service & 0.231 & 0.098 & 0.232 & 2.361 & 0.020 \\
\hline
\end{tabular}

Source: Output SPSS 25, Data processed

Based on table 11, it is known that the sig value is $0.020<0.05$. This shows that After Sales Service $\left(\mathrm{X}_{2}\right)$ has a significant effect on Consumers' Loyalty $(\mathrm{Z})$. In other words, Hypothesis $4(\mathrm{H} 4)$ is accepted.

Table 12. The Effect of Consumers' Satisfaction (Y) towards Consumers' Loyalty (Z)

\begin{tabular}{|c|c|c|c|c|c|}
\hline \multirow[t]{2}{*}{ Model } & \multicolumn{2}{|c|}{$\begin{array}{l}\text { Unstandardized } \\
\text { Coefficients }\end{array}$} & \multirow{2}{*}{$\begin{array}{c}\text { Standardize } \\
\text { d } \\
\text { Coefficients } \\
\text { Beta }\end{array}$} & \multirow[t]{2}{*}{$\mathrm{t}$} & \multirow[t]{2}{*}{ Sig. } \\
\hline & B & $\begin{array}{l}\text { Std. } \\
\text { Error }\end{array}$ & & & \\
\hline (Constant) & 19.655 & 9.921 & & 1.981 & 0.050 \\
\hline Consumers' Satisfaction & 0.751 & 0.265 & 0.275 & 2.829 & 0.006 \\
\hline
\end{tabular}

Source: Output SPSS 25, Data processed

Based on table 12, it is known that the sig value of $0.006<0.05$. This shows that Consumers' Satisfaction (Y) has a significant effect on Consumers' Loyalty (Z). In other words, Hypothesis 5 (H5) is accepted.

Table 13. Recapitulation of Influence Between Variables

\begin{tabular}{|c|c|c|c|}
\hline \multirow{2}{*}{ Variable } & \multicolumn{2}{|c|}{ Influence } & \multirow{2}{*}{ Total } \\
\hline & Direct & Indirect & \\
\hline $\mathbf{X}_{1}-\mathbf{Y}$ & 0.276 & - & 0.276 \\
\hline $\mathbf{X}_{2}-\mathbf{Y}$ & 0.293 & - & 0.293 \\
\hline $\mathbf{X}_{1}-\mathbf{Z}$ & 0.215 & - & 0.215 \\
\hline $\mathbf{X}_{2}-\mathbf{Z}$ & 0.232 & - & 0.232 \\
\hline $\mathbf{Y}-\mathbf{Z}$ & 0.275 & - & 0.275 \\
\hline \multirow{2}{*}{$\mathbf{X}_{1}-\mathbf{Y}$} & \multirow{2}{*}{ 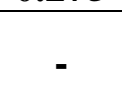 } & $\left(\mathrm{X}_{1}-\mathrm{Y}\right)(\mathrm{Y}-\mathrm{Z})$ & \multirow{2}{*}{$(0.276+0.076)=\mathbf{0 . 3 5 2}$} \\
\hline & & $0.276 \times 0.275=0.076$ & \\
\hline \multirow{2}{*}{$\mathbf{X}_{2}-\mathbf{Z}$} & \multirow{2}{*}{ - } & $\left(\mathbf{X}_{2}-\mathbf{Y}\right)(\mathbf{Y}-\mathbf{Z})$ & \multirow{2}{*}{$(0.293+0.081)=\mathbf{0 . 3 7 4}$} \\
\hline & & $0.293 \times 0.275=0.081$ & \\
\hline
\end{tabular}

Source: Output SPSS 25, Data processed

1. The indirect effect of Service Quality variable $\left(X_{1}\right)$ on Consumers' Loyalty $(Z)$ with Consumers' Satisfaction (Y) as an intervening variable is the multiplication of beta $\mathrm{X}_{1}$ value against $\mathrm{Y}$ with beta value of $\mathrm{Y}$ against $\mathrm{Z}$ that is $0.276 \times 0.275=0.076$. Furthermore, 
the total effect of Service Quality variable on Consumers' Loyalty with Consumers' Satisfaction as an intervening variable is $(0.276+0.076)=0.352$.

2. The indirect effect of After Sales Service variable $\left(X_{2}\right)$ on Consumers' Loyalty $(Z)$ with Consumers' Satisfaction (Y) as an intervening variable is the multiplication of beta $\mathrm{X}_{2}$ value against $\mathrm{Y}$ with beta value $\mathrm{Y}$ against $\mathrm{Z}$ that is $0.293 \times 0.275=0.081$. Furthermore, the total effect of After Sales Service variable on Consumers' Loyalty with Consumers' Satisfaction as an intervening variable is $(0.293+0.081)=0.374$

\section{Discussion of Research Results.}

Based on research results, it is known that Service Quality $\left(\mathrm{X}_{1}\right)$ has a positive and significant effect on Consumers' Satisfaction (Y). That is because the value of t Calculate 2,845> t Table 1,984 and sig value of $0.005<0.05$ (Ghozali, 2013: 40) so that it can be concluded that Service Quality has a positive and significant effect on Consumers' Satisfaction. This proves that service quality is one of the factors and important roots that can provide consumers' satisfaction of MangoeSky internet service PT. Telkom Satelit Indonesia (Telkomsat).

Jusuf and Efendi (2015) explained consumers' satisfaction is part of marketing and plays an important role in the market. Consumer-oriented marketing strategy makes the company should understand consumers and meet their needs to achieve consumers' satisfaction.

By creating good quality product, it will have an impact on Consumers' satisfaction, according to the statement of Tjiptono (2008) stated that product quality is closely related to Consumers' satisfaction. Quality provides a special impetus for customers to forge a long-term mutually beneficial relationship with the company.

The results of this study support previous research that was conducted by Cruz (2015) in the title "Relationship between product quality and Consumers' satisfaction" which found that Service Quality has a positive and significant effect on Consumers' satisfaction.

The results of the study, showed that After Sales Service $\left(\mathrm{X}_{2}\right)$ had a positive and significant effect on Consumers' satisfaction (Y). That is because the $t$ value of 3.033> $t$ Table 1.984 and sig value of $0.003<0.05$ (Ghozali, 2013: 40) so that it can be concluded that After Sales Service has a positive and significant effect on Consumers' satisfaction. This proves that after sales service is one of the factors that is able to provide satisfaction for customers of MangoeSky internet service PT. Telkom Satelit Indonesia (Telkomsat).

After-sales service has emerged as a major source of competitive maneuvering, so companies strive to create competitive advantage by creating after sales service portfolio with different offers from competitors (Goffin, 1994., Slater, 1996; in Ruben, 2012). Mishra (2014) also supported that after sales services is very important because it helps a business to ensure customers are satisfied after making a purchase and in cases when there are difficulties in the installation or setting of equipment, they will receive assistance. According to Ganon in Tanoto (2012) after sales service is a service provided to customers after customers buy products. Components of after sales service consist of Warranty, Availability of Spare Parts, Service Technicians, Facilities and Supporting Facilities. Companies must be able to pay attention to aspects of the after-sales service to increase the level of Consumers' satisfaction.

The results of this study are convenient with previous researches that are conducted by Rigopoulou et.al (2008), Fazizadeh et.al (2011), Choudhary et.al (2011), Egonson et.al (2013), Mishra (2014) that After-Sales Services have positive and significant impact on consumers' satisfaction.

The results of the study, showed that Service Quality $\left(X_{1}\right)$ had a positive and significant effect on Consumers' loyalty $(Z)$. That is because the t value is $2,181>t$ Table 1,984 and the sig value is $0.002<0.05$ (Ghozali, 2013: 40) so it can be concluded that Service 
Quality has a positive and significant effect on Consumers' loyalty. This proves that service quality is one of the determining factors to keep customers loyal to use MangoeSky's internet service PT. Telkom Satelit Indonesia (Telkomsat).

Service quality is a level of excellence to meet consumer desires (Tjiptono, 2015). Good service quality starts from consumer perception, not from the company. Service companies are companies that sell or offer service products for their customers (Alma, 2015). The products produced by this company are not in the form of goods but in the form of services that can only be enjoyed by consumers so that consumers cannot save the results. So, it can be said that the results or products of this company are abstract. So, that a good quality of service will give preference to consumers to reuse the company's services and recommend to others (Salomon, 2015). The result of this study supports the previous one which was conducted by Rasoli dan Jafari (2014) "The Effect of Production Quality Dimension on Customers Loyalty towards the Brand" it was stated that the service quality influenced positively and significantly towards consumers' loyalty.

The results of the study, showed that After Sales Service $\left(\mathrm{X}_{2}\right)$ had a positive and significant effect on Consumers' loyalty $(Z)$. That is because the $t$ value is 2,361>t Table 1,984 and the sig value is $0.020<0.05$ (Ghozali, 2013: 40) so it can be concluded that After Sales Service has a positive and significant effect on Consumers' loyalty. This proves by providing good after-sales service, it will have an impact on the company sustainability, because customers will not change over other companies or competitors thus indirectly it provides benefits for the company and customers remain loyal to use MangoeSky's internet service PT. Telkom Satelit Indonesia (Telkomsat).

In accordance with the statement of Bundschuh and Dezvane in Saccani et.al (2007) that after-sales service as an activity that provides revenue, profits and competitive advantages for companies and even after-sales service in the manufacturing industry will provide profits four or five times greater than sale of new products. From these results indicate that after-sales service contributes to the formation of Consumers' loyalty.

The results of this study are consistent with previous researches that are conducted by Diana Arief and Abdurrahman (2012), Egonson et.al (2013), Frab et.al (2015) stated that after sales service has a positive and significant effect on the formation of Consumers' loyalty.

The results of the study, showed that Consumers' satisfaction (Y) had a positive and significant effect on Consumers' loyalty $(\mathrm{Z})$. That is because the value of $\mathrm{t}$ Calculate $2,829>\mathrm{t}$ Table 1,984 and sig value of $0.006<0.05$ (Ghozali, 2013: 40) so it can be concluded that Consumers' satisfaction has a positive and significant effect on Consumers' loyalty. This shows that Consumers' satisfaction is an important factor that must be considered by MangoeSky's internet service PT. Telkom Satelit Indonesia (Telkomsat) to maintain Consumers' loyalty.

Every company competes to provide the best facilities and offers for consumers' satisfaction. It is very dependent on customer performance and expectations. Satisfaction is the level of one's feelings after comparing the perceived performance or outcome with the expected expectations of the product (Kotler et. Al, 2007).

Satisfaction which is felt by customers has behavioral consequences in the form of complaints and Consumers' loyalty, thus if the organization or company able to pay attention to all things that can shape Consumers' satisfaction, then the satisfaction felt by the customer as a whole will be formed so that it will have a good impact on the company because consumers will be loyal to the services provided and decides to make purchases on an ongoing basis (Mujianto, 2017). 
In order to create a climate of loyal customers in a product or service produced by a company there must be an effort to give birth to Consumers' satisfaction. If the quality of services provided is good, it will cause the customer to be satisfied and if the customer is satisfied, he will make a repeat purchase of the service he has used. Consumers' loyalty means a condition where consumers have a positive attitude towards a brand, are committed to the brand, and intend to continue their purchases in the future (Alma, 2015).

The results of this study are in line with previous studies conducted by Aryani \& Rosita (2010), Mulyono (2008), Diana Arief and Abdurrahman (2012), Kusuma et.al (2014), that Consumers' satisfaction has a positive and significant effect on loyalty customer.

There is an indirect effect between Service Quality on Consumers' loyalty with a positive Consumers' satisfaction that is equal to 0.076, then the total effect of Service Quality variables on Consumers' loyalty with a positive Consumers' satisfaction is 0.352 . While the indirect effect between After Sales Service on Consumers' loyalty with positive Consumers' satisfaction is equal to 0.081 , then the total effect of After Sales Service variable on Consumers' loyalty with positive Consumers' satisfaction is 0.374 .

\section{CONCLUSIONS AND RECOMMENDATIONS \\ Conclusion:}

1. Based on the result of the study, it is known that Service Quality has a positive and significant effect on Consumers' satisfaction. By creating good product quality, it will have an impact on Consumers' satisfaction, because good product quality will provide a special impetus for customers to establish a long-term mutually beneficial relationship with the company.

2. Based on the results of the study, it showed that After Sales Service has a positive and significant effect on Consumers' satisfaction. This is because after-sales service has emerged as the main source for companies to compete with competitors. With this aftersales service the company strives to create competitive advantage by creating new portfolios that are different from competitors. After-sales service seems to be very important for companies engaged in the service sector, this is because these services can help companies to ensure customers feel satisfied or not after making a purchase.

3. Based on the results of the study, it is known that Service Quality has a positive and significant effect on Consumers' loyalty. Because the quality of service is one of the determining factors for maintaining customers to remain loyal (loyal) with the products or services that have been provided by the company. If a company is able to present a product or service of good quality to its customers, then that customer will reuse the company's products or services and recommend it to others.

4. Based on the results of the study, it showed that After Sales Service has a positive and significant effect on Consumers' loyalty. Providing good after-sales service will have an impact on the company sustainability, because customers will not change over to other companies or competitors so that it will indirectly provide benefits for companies four or five times greater than sales of new products and customers remain loyal to use products or previously purchased service. This shows that after sales services also contribute to the formation of Consumers' loyalty.

5. Based on the research results, it is known that Consumers' satisfaction has a positive and significant effect on Consumers' loyalty. If the quality of the service provided is good, it will cause the customer to be satisfied and if the customer is satisfied, he will make a repeat purchase of the product or service he has used. Satisfaction felt by customers has behavioral consequences in the form of complaints and Consumers' loyalty, so that if the organization or company can pay attention to all things that can shape Consumers' 
satisfaction, then the satisfaction felt by the customer as a whole will be formed so that it will have a good impact on the company because consumers will loyal to the services provided and decides to make purchases on an ongoing basis.

6. Based on the results of the study, it is known that there is a positive indirect effect between Service Quality and After Sales Service on Loyalty through Consumers' satisfaction, meaning that if the customer is satisfied with the quality of the service provided, it can increase Consumers' loyalty.

\section{Recommendations:}

1. In this study it is known that in order to increase Consumers' satisfaction, customers of MangoeSky Satellite Internet Products PT. Telkomsat, companies should be able to use After Sales Service variables with the Service Technician dimension (AS3). It is known that the influence of Technician Services on Consumers' satisfaction is the lowest. Customers will increase satisfaction if the company provides technicians service and make maximum network repairs when there is a disruption in the MangoeSky Satellite Internet connection. PT. Telkomsat must provide technician services that are scattered in several locations closest to the customer and provide supporting facilities such as the ease of contacting the MangoeSky Call Center for reports of disturbance or damage recorded in the Customer Relationship Management (CRM) system. So that through CRM, a history of disturbance or damage reports that have been handled or not yet resolved can be recorded. So that the MangoeSky internet service provided will be stable under any conditions including even in bad weather conditions, because it is supported by maximum Technician Services.

2. In this study, it is known that MangoeSky Satellite Internet Products of PT. Telkomsat should always improve its After Sales Service where the dimension of Spare Parts Availability (AS2) is the lowest effect on loyalty, it means that PT. Telkomsat must provide Availability of MangoeSky Satellite Internet Product Equipment Parts that are scattered in several locations closest to the customer, thus when there is damage to one of MangoeSky Satellite Internet Products devices, the technician can immediately repaired and replaced without having to make customers wait too long without any certainty when damage to the device will be handled properly. Thus, customer will feel that the after sales service provided by PT. Telkomsat is good and maximal, it will make customers feel satisfied and will make a repurchase which has an impact on Consumers' loyalty for MangoeSky Satellite Internet Products.

3. This research focuses on 4 studies of variables namely service quality, after sales service, consumers' satisfaction and consumers' loyalty so that the use of other variables such as price, brand image and other variables needs to be done in future research in order to produce a broader picture of the problem research that is being researched.

\section{REFERENCES}

Aryani, D dan Rosita F. (2010). Pengaruh Kualitas layanan terhadap kepuasan pelanggan dalam membentuk loyalitas pelanggan. Bisnis \& Birokrasi jurnal ilmu administrasi dan organisasi. Vol.17 No. 2, pp:114-116. ISSN 0854-3844.

Arief D., Abdurahman K dan Sudirman I. (2012). Pengaruh Kualitas Produk dan Layanan Purna Jual terhadap Kepuasan dan Loyalitas Pelanggan pada Pelanggan Pengguna Motor Honda di Makasar. Jurnal Manajemen Keuangan .Universitas Hasanudin. Makasar.

Ardiansyah., Arifin R dan Priyono. (2014). Pengaruh pelayanan purnajual terhadap loyalitas pelanggan sepeda motor honda pada pt mitra kencana perkasa. Journal Ilmiah Manajemen, Unisma. Malang. 
Asghar AJ, Hajizadeh A, Mirdamadi SA, Nawaser K dan Khaksar SM. (2011). Study the Effects of Customer Service and Product Quality on Customer Satisfaction and Loyalty. International Journal of Humanities and Social Science Vol 1 No 7.

Ashari dan Santoso P. (2005). Analisis Statistic dengan Microsoft Exel dan SPSS. Yogyakarta.

Budihardja S dan Venusita L. (2012). Pengaruh Pelayanan Purna Jual terhadap Customer Satisfaction dalam Kegiatan Customer Service pada Balanced Scorecard. Jurnal Penelitian Universitas Widya Kartika.

Cakrawati, EA. (2011). "Pengaruh Kualitas Produk dan Pelayanan Purna Jual Terhadap Kepuasan Pengguna Ban Achilles". Tesis Pascasarjana. Universitas Esa Unggul. Jakarta.

Choudhary AI, Akhter SA, Asif M, Choudhry RM, Siddique Z, Mughal. (2011). Impact Of After Sales Service Characteristics on Customer Satisfaction. Information Management anf Business Review, Vol 3, pp:360-365.

Cruz, Albert V. (2015). Relationship betwen product quality andcustomer satisfaction. Tesis. Walden University.

Elsandra Y dan Suryadi. (2016). Pengaruh Kualitas Produk dan Layanan Purna Jual terhadap Kepuasan Pelanggan Pada PT. Sharp Electronic Indonesia di Kota Padang. Tesis Pascasarjana. Universitas Dharma Andalas. Padang.

Egonsson E., Bayarsaikhan K dan Ting T. (2013). After sales services and customer relationship marketing-A multiple case study within the Swedish heavy equipment machinery Industry. Tesis. Linneaus University.

Fazizadeh A., Bagherzadh F dan Mohamadi P. (2011). How After Sales Service Quality Dimension Affect Customer Satisfaction. African Journal of Busines Management, Vol 5(17), pp:7658-7664.

Frab A., Garrigos JA., dan Schoeneberg KP. (2015). Impact of After-Sales Performances of German Automobile Manufacturers in China in Service Satisfaction and Loyalty: With a Particular Focus on the Influences of Cultural Determinants. $1^{\text {st }}$ International Conference on Business Management. Universitat Politecnica de Valencia.

Gairdelli P., Saccani N., dan Songini L. (2007). Performance Measurement System in After Sales Service: an Intergrated Framework. Int.J.Business Performance Management, pp:145-171.

Ghozali, Imam. (2005). Aplikasi Analisis Multivariate dengan Program SPSS. Badan Penerbit Universitas Diponegoro. Semarang. Handoko, T.Tani. (2003). Manajemen. Cetakan ke-12. BPFE Yogyakarta. Yogyakarta.

Grifin, Jill. (2005). Customer Loyalty: Menumbuhkan dan mempertahankan Kesetiaan Pelanggan. Edisi revisi dan terbaru. Erlangga. Jakarta.

Hardiansyah I. (2008). Analisis Pengaruh Kualitas Produk dan Layanan Purna Jual terhadap Loyalitas Pelanggan Auto 2000 di Jakarta. Tesis. Institut Pertanian Bogor.

Hasan, Ali. (2009). Marketing. Medpress. Yogyakarta.

Hurriyati, Ratih. (2005). Bauran Pemasaran dan Loyalitas Konsumen. Alfabeta. Bandung. Isaac L., Adevemo., Ogunleve. (2013). Impact of after sales service on consumer satisfaction and retention. A study of LG Electronic in Ibadan, Nigeria. IOSR Journal of Business and Management, Vol 11 pp: 54-58.

Istijanto. (2005). Aplikasi Praktis Riset Pemasaran. PT Gramedia. Jakarta Jayawardhena C. (2010). "The impact of service encounter quality in service evaluation: evidence from a business-to-business context "The Journal of Business \& Industrial 
Marketing. Vol.25. Issue. 5. pp: 338-348 Emerald Group Publishing, Limited. United Kingdom.

Kotler, P. (2005). Manajemen Pemasaran di Indonesia. Buku 2. Diadapatasi oleh A.B. Susanto 2001. Salemba 4. Jakarta.

Kotler P dan Keller KL. (2012). Manajemen Pemasaran Edisi 12 Jlid 1. PT. Gramedia Pustaka Utama.Jakarta.

Kurniawan A dan Wardoyo P. (2011). Analisis Tingkat Kepuasan Pemakai Alat Berat Merk Caterpillar Terhadap Layanan Purna Jual di Jawa Tengah. Jurnal Penelitian Universitas Diponegoro. Semarang.

Masyudzulhak. (2012). Memahami Penulisan Ilmiah dan Metodologi Peneitian. Lembaga Pengakajian dan Pengembagan Sumber Daya. Bengkulu.

Mulyono, B. (2008). Analisis Pengaruh Kepuasan Kualitas Produk Dan Kualitas Layanan Terhadap Kepuasan Konsumen (studi kasus pada perumahan Puri Mediterania Semarang)". Tesis Pascasarjana. Universitas Diponegoro. Semarang.

Rasoli M dan Jafari A. (2014). The Effect of Production Quality Dimension on Customers Loyalty towards the Brand. Journal of Applied Business and Finance Researches, Vol 3, pp:19-22.

Ruben, J. (2012). Managing After Sales Services: Strategis and Inter Firm Relationship. $\mathrm{PhD}$ Thesis of Diph-Kfm Technic. Universitatstuttgat.

Sangadji dan Sopiah. (2013). Perilaku Konsumen-Pendekatan Praktis Disertai Himpunan Jurnal Penelitian. Edisi I. CV Andi. Yogyakarta.

Sugiono. (2008). Metode Penelitian Bisnis.Cetakan ke-12. Alfabeta. Bandung Tanoto, DW. (2014). Analisis pengaruh kualitas produk dan after sales service terhadap kepuasan konsumen yang berdampak pada loyalitas pelanggan di PT Asia Pacific True Trust. Tesis. Bina Nusantara University. Jakarta.

Tjiptono,Fandy. (2008). Strategi Bisnis Pemasaran. Andi. Yogyakarta.

Tjiptono F dan Chandra G. (2012). Pemasaran Strategic Edisi 2. Penerbit Andi Offset. Yogyakarta.

Lampung. Tesis Pascasarjana. Universitas Lampung.

Sitio.Arifin, (2019). Strategi pemasaran UMKM, Mutiara Bantten. Banten. 